・保护论坛・

\title{
中国森林覆盖度产品的差异性及不确定性分析
}

\author{
秦元伟 ${ }^{1}$ 董金玮 ${ }^{1}$ 肖向明 $1,2^{*}$ \\ 1 (俄克拉荷马大学微生物与植物生物系、空间分析中心, 诺曼, 俄克拉荷马 73019, 美国) \\ 2 (复旦大学生物多样性科学研究所, 上海 200433, 中国)
}

\section{Difference and uncertainty of forest coverage estimation in China}

\author{
Yuanwei Qin ${ }^{1}$, Jinwei Dong ${ }^{1}$, Xiangming Xiao ${ }^{1,2 *}$ \\ 1 Department of Microbiology and Plant Biology, Center for Spatial Analysis, University of Oklahoma, Norman, OK \\ 73019, USA \\ 2 Institute of Biodiversity Science, Fudan University, Shanghai 200433, China
}

森林具有气候调节、水源涵养、生物多样性保 护等诸多生态服务功能 (Millennium Ecosystem Assessment, 2005; van der Werf et al., 2009), 同时减 少毁林和森林退化也是减缓温室气体排放协议 REDD+的重要内容(DeFries et al., 2007; Grassi et $a l .$, 2008)。为了改善日益恶化的生态状况，提高森 林资源的蓄积量, 自 20 世纪70年代以来, 中国实施 了六大林业重点工程，包括天然林保护工程、“三 北” 和长江中下游地区等重点防护林体系建设工 程、退耕还林还草工程、京津风沙源治理工程、野 生动植物保护及自然保护区建设工程以及重点地 区速生丰产用材林为主的林业产业建设工程。在森 林砍伐和林业工程的双向驱动下, 如何准确地监测 中国森林覆盖度及其时空变化成为一大挑战。

王吴等(2015) 基于 Global Forest Watch网站 (http://www.globalforestwatch.org/)上发布的 $30 \mathrm{~m}$ 空 间分辨率的全球森林数据集, 详细解读了 2000-2010年中国森林面积及其变化, 并与同期其 他森林数据进行了比较。研究结果认为 Global Forest Watch数据质量可靠, 其与GlobeLand30数据 集的森林分布有较高的空间吻合度，建议增加该数 据集在保护生物学中的应用。该对比研究有助于了 解当前不同中国森林数据产品的异同, 对促进森林 的精准制图及其在保护生物学中的应用具有一定
的启示作用。

GlobeLand 30 森林数据的精度在 $80 \%$ 左右 (Chen et al., 2015), 其与Global Forest Watch的空间 重合度 $(78.97 \%$ 、83.94\%、89.24\%和92.93\%)随着森 林覆盖度 $(>0$ 、 $>20 \%$ 、 $>50 \%$ 和 $>75 \%)$ 的增加而增加 (王吴等, 2015), 但两者在森林稀疏地区仍有较大的 空间不确定性。Global Forest Watch显示2000-2010 年中国森林面积的减少在37,551-42,031 $\mathrm{km}^{2}$ 之间, 而同期ChinaCover、森林清查、FAO FRA和NLCD 显示森林面积的增加在 2,370-433,810 $\mathrm{km}^{2}$ 之间(王 昊等, 2015)。这也说明上述森林产品估算的中国森 林面积尚具有较大的不确定性。本文收集了2010年 主要森林数据产品(表1), 从森林定义、数据源、训 练数据和结果验证数据、森林监测算法等方面探讨 了中国森林覆盖度产品的差异及其原因, 以期为实 现中国森林覆盖度的精准监测提供科学参考。

\section{1 森林的定义}

森林的定义主要包括森林的覆盖度和树高。现 有森林定义中, 森林的最小覆盖度从 $10 \%$ 到 $60 \%$ 不 等, 最低树高从 $0.3 \mathrm{~m}$ 到 $5 \mathrm{~m}$ 不等, 差别较大。以 Global Forest Watch森林图为例, 覆盖度 $\geq 10 \%$ 和 $\geq$ $30 \%$ 的森林面积相差 $19.3 \times 10^{6} \mathrm{~km}^{2}$, 约占全球陆地 面积的 $13 \%$ (Sexton et al., 2015)。因此, 不同的森林

收稿日期: 2015-11-23; 接受日期: 2015-11-24

基金项目: NASA 土地利用/覆盖变化项目(NNX11AJ35G、NNX14AD78G)、美国国家科学基金 EPSCoR 项目(IIA-1301789)、美国国立卫生研究院项目 (1R01AI101028-01A1)和国家自然科学基金(41571408)

* 通讯作者 Author for correspondence. E-mail: xiangming.xiao@ou.edu 


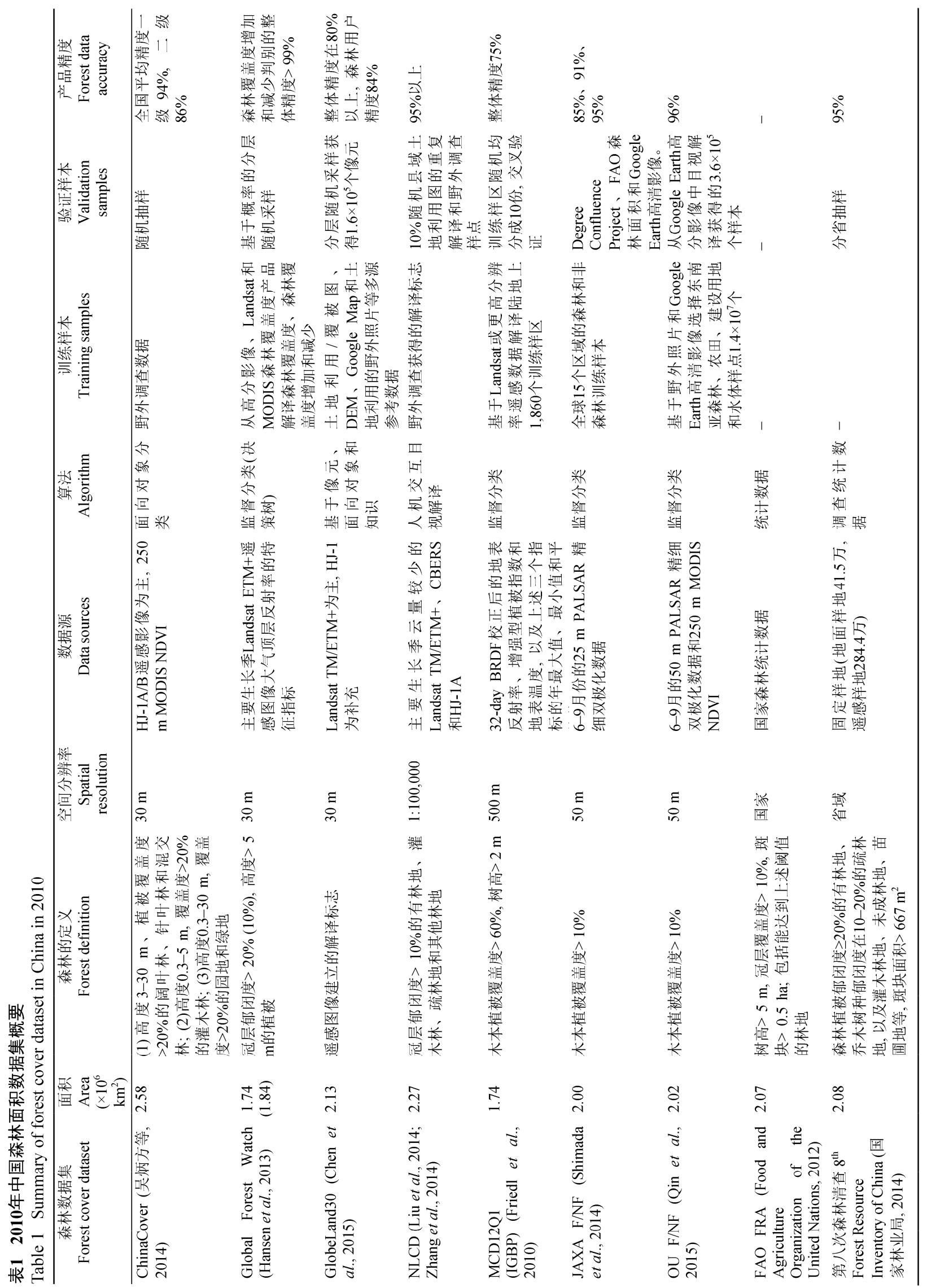


定义被认为是导致森林产品存在较大差异和不确 定性的主要原因(Qin et al., 2015; Sexton et al., 2015)。

\section{2 森林监测的数据源}

(1) Landsat 和 HJ-1 遥感数据是 ChinaCover、 GlobeLand30、Global Forest Watch和NLCD的主要 数据源, 其空间分辨率较高, 可有效降低混合像元 的影响, 但观测频率较低, 易受云和阴影的影响(Ju \& Roy, 2008)。ChinaCover、GlobeLand30和NLCD 使用无云和少云的单景遥感影像(Liu et al., 2014; Zhang et al., 2014; 吴炳方等, 2014; Chen et al., 2015), 而Global Forest Watch使用了主要生长季的 所有Landsat ETM+大气顶层的反射率数据, 增加了 数据的利用效率, 并进行了无效观测值的去除和图 像均一化预处理(Hansen et al., 2013)。

(2) BRDF校正后的地表反射率、增强型植被指 数和地表温度, 以及上述三个指标的年最大值、最 小值和平均值是MCD12Q1的主要数据源, 其空间 分辨率较粗, 混合像元较多, 但观测频率较高, 适 合于大面积森林制图(Friedl et al., 2010)。

(3) ALOS PALSAR的精细双极化数据是JAXA FNF的主要数据源, 其不受天气状况的影响, 但易 受地形和土壤含水量的影响。地形校正和滤波往往 用于去除其斑点噪声(Shimada et al., 2014)。

(4) ALOS PALSAR 的精细双极化数据和 MODIS NDVI是OU FNF的主要数据源, 两种数据 的融合综合了森林的结构、生物量和光谱信息, 有 效降低了森林的误判(Qin et al., 2015)。

(5) 调查和统计数据是中国第八次森林清查和 FAO FRA的主要数据源, 该数据能刻画森林宏观变 化趋势, 但空间分辨率较粗(Food and Agriculture Organization of the United Nations, 2012; 国家林业 局, 2014)。

\section{3 算法训练数据和结果验证数据}

以遥感数据为数据源的森林覆盖度监测通过 野外调查数据、高分影像等建立森林和非森林的训 练样本或解译标志。训练样本和解译标志的数量、 空间分布和代表性直接决定了森林监测算法的阈 值。基于调查和统计数据的第八次森林清查和FAO FRA则不需要训练数据。森林覆盖度结果的验证主
要通过随机采样、分层随机采样或者野外调查数据 进行精度评价。

\section{4 森林覆盖度估算方法}

(1)人机交互目视解译。需要大量的人力物力, 效率相对较低, 且年际间的稳定性和可比性较差, 解译精度取决于遥感数据的质量和解译人员的专 业判断。

(2)自动分类算法，包括监督分类、面向对象分 类和基于像元、面向对象和知识的分类。该方法基 于训练样本获得的阈值进行自动分类, 并可引入专 家知识等提高分类精度、效率较高，结果在年际间 的稳定性和可比性较好。

(3)调查统计数据。基于上百万个固定样地的调 查结果被认为是可靠的，被广泛地用于估算森林面 积和生物量的变化, 但需要大量的人力物力、 5-10 年调查和数据分析周期(Fang et al., 2001, 2014)。

\section{5 小结与讨论}

森林定义的差异是森林数据空间和面积不确 定性的主要原因, 因此, 今后森林制图可以采用相 似的森林定义。大尺度森林制图需要大量的野外调 查数据和样本数据进行算法训练和结果验证, 森林 样本数据的共享可以提高大尺度森林遥感监测的 效率和准确度。俄克拉荷马大学地球观测和模拟研 究中心(Earth Observation and Modeling Facility)建 立了全球野外照片数据库开放共享平台 (http://www.eomf.ou.edu/photos/), 长期致力于促进 科研人员共享野外调查数据, 推动大尺度土地利用 /覆被分类制图的发展(Xiao et al., 2011)。目前该平 台已有超过 15 万张覆盖全球的野外照片。

AVHRR、MODIS、Landsat、Sentinel、CBERS 和 $\mathrm{HJ}$ 等遥感数据的开放获取极大丰富了森林遥感 制图的数据源，其中AVHRR和Landsat均可回溯到 20 世纪70年代。充分利用每一个有效观测的像元进 行大尺度森林制图, 需要构建海量遥感数据的存储 能力和运算能力, 如Google Earth Engine的云计算 (Hansen et al., 2013), 其效率和结果年际间的稳定 性和可比性较高。

光学遥感能够反映森林的绿度和物候信息, 雷 达遥感能够反映森林的空间结构和地上生物量信 息, 激光遥感能有效探测森林的高度和冠层结构信 
息, 叶绿素荧光数据能够探测森林的光合作用强

度。因此, 促进多源遥感数据的融合, 发挥不同传 感器的优势, 将促进森林面积(Dong et al., 2012a; Qin et al., 2015)、树高(Simard et al., 2011; Cartus et al., 2012)、树密度(Crowther et al., 2015)、树龄 (Kou et al., 2015)、地上生物量 (Saatchi et al., 2011; Peregon \& Yamagata, 2013)和总初级生产力GPP (Damm et al., 2010)的多角度、多层次监测。

根据第八次森林清查, 中国人工林(桉树、橡胶 等)面积占森林面积的 $36 \%$, 但蓄积量只占 $17 \%$ (国 家林业局, 2014)。人工林取代天然林对生态往往具 有负面效应, 难以替代天然林在生物多样性保护和 生态服务等方面的作用 (Barlow et al., 2007; Meyfroidt \& Lambin, 2011)。因此, 采用遥感技术进 行大尺度人工林的长时间序列遥感监测有助于掌 握其时空格局, 为分析其生态效应和制定人工林的 发展规划、天然林保护等政策提供数据基础和科学 依据(Dong et al., 2012b, 2013; le Maire et al., 2014; Kou et al., 2015)。

\section{参考文献}

Barlow J, Gardner TA, Araujo IS, Avila-Pires TC, Bonaldo AB, Costa JE, Esposito MC, Ferreira LV, Hawes J, Hernandez MM, Hoogmoed MS, Leite RN, Lo-Man-Hung NF, Malcolm JR, Martins MB, Mestre LAM, Miranda-Santos R, Nunes-Gutjahr AL, Overal WL, Parry L, Peters SL, Ribeiro-Junior MA, da Silva MNF, Motta CD, Peres CA (2007) Quantifying the biodiversity value of tropical primary, secondary, and plantation forests. Proceedings of the National Academy of Sciences, USA, 104, 18555-18560.

Cartus O, Kellndorfer J, Rombach M, Walker W (2012) Mapping canopy height and growing stock volume using airborne lidar, ALOS PALSAR and Landsat ETM. Remote Sensing, 4, 3320-3345.

Chen J, Chen J, Liao AP, Cao X, Chen LJ, Chen XH, He CY, Han G, Peng S, Lu M, Zhang WW, Tong XH, Mills J (2015) Global land cover mapping at $30 \mathrm{~m}$ resolution: A POK-based operational approach. ISPRS Journal of Photogrammetry and Remote Sensing, 103, 7-27.

Crowther TW, Glick HB, Covey KR, Bettigole C, Maynard DS, Thomas SM, Smith JR, Hintler G, Duguid MC, Amatulli G, Tuanmu MN, Jetz W, Salas C, Stam C, Piotto D, Tavani R, Green S, Bruce G, Williams SJ, Wiser SK, Huber MO, Hengeveld GM, Nabuurs GJ, Tikhonova E, Borchardt P, Li CF, Powrie LW, Fischer M, Hemp A, Homeier J, Cho P, Vibrans AC, Umunay PM, Piao SL, Rowe CW, Ashton MS, Crane PR, Bradford MA (2015) Mapping tree density at a global scale. Nature, 525, 201-207.

Damm A, Elbers J, Erler A, Gioli B, Hamdi K, Hutjes R, Kos- vancova M, Meroni M, Miglietta F, Moersch A, Moreno J, Schickling A, Sonnenschein R, Udelhoven T, van der Linden S, Hostert P, Rascher U (2010) Remote sensing of sun-induced fluorescence to improve modeling of diurnal courses of gross primary production (GPP). Global Change Biology, 16, 171-186.

DeFries R, Achard F, Brown S, Herold M, Murdiyarso D, Schlamadinger B, de Souza C (2007) Earth observations for estimating greenhouse gas emissions from deforestation in developing countries. Environmental Science \& Policy, 10, 385-394.

Dong JW, Xiao XM, Chen BQ, Torbick N, Jin C, Zhang GL, Biradar C (2013) Mapping deciduous rubber plantations through integration of PALSAR and multi-temporal Landsat imagery. Remote Sensing of Environment, 134, 392-402.

Dong JW, Xiao XM, Sheldon S, Biradar C, Duong ND, Hazarika M (2012a) A comparison of forest cover maps in Mainland Southeast Asia from multiple sources: PALSAR, MERIS, MODIS and FRA. Remote Sensing of Environment, 127, 60-73.

Dong JW, Xiao XM, Sheldon S, Biradar C, Xie GS (2012b) Mapping tropical forests and rubber plantations in complex landscapes by integrating PALSAR and MODIS imagery. ISPRS Journal of Photogrammetry and Remote Sensing, 74, 20-33.

Fang JY, Chen AP, Peng CH, Zhao SQ, Ci LJ (2001) Changes in forest biomass carbon storage in China between 1949 and 1998. Science, 292, 2320-2322.

Fang JY, Guo ZD, Hu HF, Kato T, Muraoka H, Son Y (2014) Forest biomass carbon sinks in East Asia, with special reference to the relative contributions of forest expansion and forest growth. Global Change Biology, 20, 2019-2030.

Food and Agriculture Organization of the United Nations (2012) Global Forest Resource Assessment (FRA) 2010: Main Report. Rome, Italy.

Friedl MA, Sulla-Menashe D, Tan B, Schneider A, Ramankutty N, Sibley A, Huang XM (2010) MODIS Collection 5 global land cover: Algorithm refinements and characterization of new datasets. Remote Sensing of Environment, 114, 168-182.

Grassi G, Monni S, Federici S, Achard F, Mollicone D (2008) Applying the conservativeness principle to REDD to deal with the uncertainties of the estimates. Environmental Research Letters, 3, 1-12.

Hansen MC, Potapov PV, Moore R, Hancher M, Turubanova SA, Tyukavina A, Thau D, Stehman SV, Goetz SJ, Loveland TR, Kommareddy A, Egorov A, Chini L, Justice CO, Townshend JRG (2013) High-resolution global maps of 21 st-century forest cover change. Science, 342, 850-853.

Ju JC, Roy DP (2008) The availability of cloud-free Landsat ETM plus data over the conterminous United States and globally. Remote Sensing of Environment, 112, 1196-1211.

Kou WL, Xiao XM, Dong JW, Gan S, Zhai DL, Zhang GL, Qin YW, Li L (2015) Mapping deciduous rubber plantation areas and stand ages with PALSAR and landsat images. Remote Sensing, 7, 1048-1073. 
le Maire G, Dupuy S, Nouvellon Y, Loos RA, Hakarnada R (2014) Mapping short-rotation plantations at regional scale using MODIS time series: case of eucalypt plantations in Brazil. Remote Sensing of Environment, 152, 136-149.

Liu JY, Kuang WH, Zhang ZX, Xu XL, Qin YW, Ning J, Zhou WC, Zhang SW, Li RD, Yan CZ, Wu SX, Shi XZ, Jiang N, Yu DS, Pan XZ, Chi WF (2014) Spatiotemporal characteristics, patterns, and causes of land-use changes in China since the late 1980s. Journal of Geographical Sciences, 24, 195-210.

Meyfroidt P, Lambin EF (2011) Global forest transition: prospects for an end to deforestation. Annual Review of Environment and Resources, 36, 343-371.

Millennium Ecosystem Assessment (2005) Ecosystems and Human Well-being: Synthesis. Island Press, Washington, DC.

Peregon A, Yamagata Y (2013) The use of ALOS/PALSAR backscatter to estimate above-ground forest biomass: a case study in Western Siberia. Remote Sensing of Environment, 137, 139-146.

Qin YW, Xiao XM, Dong JW, Zhang GL, Shimada M, Liu JY, Li CG, Kou WL, Moore III B (2015) Forest cover maps of China in 2010 from multiple approaches and data sources: PALSAR, Landsat, MODIS, FRA, and NFI. ISPRS Journal of Photogrammetry and Remote Sensing, 109, 1-16.

Saatchi SS, Harris NL, Brown S, Lefsky M, Mitchard ETA, Salas W, Zutta BR, Buermann W, Lewis SL, Hagen S, Petrova S, White L, Silman M, Morel A (2011) Benchmark map of forest carbon stocks in tropical regions across three continents. Proceedings of the National Academy of Sciences, USA, 108, 9899-9904.

Sexton JO, Noojipady P, Song XP, Feng M, Song DX, Kim DH, Anand A, Huang C, Channan S, Pimm SL, Townshend JR (2015) Conservation policy and the measurement of forests. Nature Climate Change, doi: 10.1038/nclimate2816.

Shimada M, Itoh T, Motooka T, Watanabe M, Shiraishi T, Thapa R, Lucas R (2014) New global forest/non-forest maps from ALOS PALSAR data (2007-2010). Remote Sensing of Environment, 155, 13-31.
Simard M, Pinto N, Fisher JB, Baccini A (2011) Mapping forest canopy height globally with spaceborne lidar. Journal of Geophysical Research: Biogeosciences, 116.

State Forestry Administration of the People's Republic of China (国家林业局) (2014) General Situation of Forest Resource in China: 8th Forest Resource Inventory (中国森林资源简 况: 第八次全国森林资源清查). (in Chinese)

van der Werf GR, Morton DC, DeFries RS, Olivier JGJ, Kasibhatla PS, Jackson RB, Collatz GJ, Randerson JT (2009) $\mathrm{CO}_{2}$ emissions from forest loss. Nature Geoscience, 2, 737-738.

Wang H (王吴), Lü Z (吕植), Gu L (顾垒), Wen C (闻丞) (2015) Observations of China's forest change (2000-2013) based on Global Forest Watch dataset. Biodiversity Science (生物多样性), 23, 575-582. (in Chinese with English abstract)

Wu BF (吴炳方), Yuan QZ (苑全治), Yan CZ (颜长珍), Wang ZM (王宗明), Yu XF (于信芳), Li AN (李爱农), Ma RH (马荣华), Huang JL (黄进良), Chen JS (陈劲松), Chang C (常存), Liu CL (刘成林), Zhang L (张磊), Li XS (李晓松), Zeng Y (曾源), Bao AM (包安明) (2014) Land cover changes of China from 2000 to 2010. Quaternary Sciences (第四纪研究), 34, 723-731. (in Chinese with English abstract)

Xiao XM, Dorovskoy P, Biradar C, Bridge E (2011) A library of georeferenced photos from the field. Eos, Transactions American Geophysical Union, 92, 453-454.

Zhang ZX, Wang X, Zhao XL, Liu B, Yi L, Zuo LJ, Wen QK, Liu F, Xu JY, Hu SG (2014) A 2010 update of National Land Use/Cover Database of China at 1:100000 scale using medium spatial resolution satellite images. Remote Sensing of Environment, 149, 142-154. 